\title{
IMAGINING HELL: A Burkeian Analysis of Indonesian Religious Afterlife Images
}

\author{
Peter Suwarno \\ Arizona State University \\ e-mail: peter.suwarno@asu.edu
}

\begin{abstract}
This paper is not only dealing with depiction of hell (divine punishment) which is very popular depicted by the speech and media news in Indonesia, but also description on meaning, and the possibility on motive behind that description. Applying Burke theory on logology, this paper revealed that the depiction of hell punishment constituted the ritual of purity. Based on the cycle of order, feeling of guilty, redemption through sacrifice to achieve the purity, general depiction on hell are a reflection of the challenges and complexity of legal rules and regulation that exactly will be broken off. This violation of the rule creates a sense of guilty and sin which come out as all the problems and difficulties that the majority of Indonesian must hold - the situation that generates scapegoat. The victims of the scapegoat became the apparent sinners, and the punishment is the sacrifaction which create satisfaction and a sense of clean up.

$* * *$

Tulisan ini tidak hanya untuk membahas penggambaran neraka (hukuman akhirat) yang sangat populer sebagaimana digambarkan dalam pidato dan media di Indonesia, tetapi juga untuk mengungkapkan makna dan kemungkinan motif di balik gambaran tersebut. Dengan teori logologi Burke, tulisan ini mengungkapkan bahwa penggambaran siksaan neraka merupakan ritual pemurnian. Berdasarkan siklus ketertiban, rasa bersalah, penebusan melalui pengorbanan untuk mencapai kemurnian, gambaran hukuman di neraka adalah cerminan dari tantangan dan kompleksitas aturan dan hukum yang pasti akan dilanggar. Pelanggaran ini menciptakan rasa bersalah dan dosa yang diwujudkan dalam bentuk semua masalah dan kesulitan bahwa mayoritas penduduk Indonesia harus tahan-situasi yang menimbulkan kambing hitam. Para korban yang merupakan kambing hitam menjadi orang berdosa terkutuk, yang hukumannya merupakan sebuah pengorbanan, menciptakan kepuasan dan rasa dibersihkan.
\end{abstract}

Keywords: imagining, hell, Burke theory, scapegoats, sacrifice 


\section{A. Preface}

If you live in and become part of an Indonesian community, it is almost inevitable that you will be exposed to religious rhetoric. This is true not only during prayers in places of worships, bible study groups, or neighborhood Quranic recital gatherings, but also in any traditional events such as weddings, circumcisions, and neighborhood meetings as well as displays of artwork and images in various Indonesian media.

One of the most interesting characteristics of any religious discourse is its classic antitheses, including the depiction of good versus evil, moral versus immoral, believers versus non-believers, reward versus punishment, and heaven versus hell. Accordingly, most religious discourses focus on the importance of afterlife as the main theme, and thus, strongly advocate preparation for the eternal afterlife. This paper focuses on examining images of afterlife which become the ultimate goal of Indonesian religious practices and which mirror the importance of reward (heaven) and punishment (hell).

Although heaven and hell are both frequently discussed, there seems to be a more graphic and detailed description of hell than of heaven. Standford ${ }^{1}$, for example, argues that it is more difficult to contemplate about heaven than about hell. Description of heaven is often condensed and generalized, because the glory and happiness of heaven is considered beyond human experience on earth. The description of hell, on the other hand, involves tragic, severe, agonizing events which are readily comparable to the suffering that a number of people experience on earth. There have been news and stories detailing experiences of suffering that some people have to endure, including natural disasters such as fire, storms, flood, volcano, and earthquake, as well as manmade tortures such as wars, murders, mutilations, kidnappings, and rapes. Humans are more accustomed to the images of hell, in part because hell, more than heaven, has been continuously depicted in various media and places of worship throughout the history of mankind ${ }^{2}$ and has been the "monstrous invention of poets and painters."3

1 Peter Stanford, The Devil: A Biography (London: William Heinemann Ltd), 1996.

${ }^{2}$ Alice K. Turner, The History of Hell (New York: Harcourt Brace \& Company), 1993.

${ }^{3}$ Charles Seymour, A Theodicy of Hell: Studies in Philosophy and Religion 20 (Dordrecht, The Netherlands: Kluwer Academic Publishers, 2000) p. 28 
Hell, more than heaven, is frequently exploited to manipulate human consciousness for various motives. As early as in Greek era, hell has been claimed to have benefits for safeguarding civic virtue of the society. ${ }^{4}$ Although during the Roman time there was a strong argument that fear of hell might drive people to do anything ${ }^{5}$ since they have nothing to lose, Cicero ${ }^{6}$ argues that the images of hell can be exploited successfully to maintain societal virtues as well as encourage actions and behavior that benefit society. Stanford 7 also agrees that images of afterlife reinforce religious commitment as well as strengthen the religious groups. In addition, these images may be used to entice more followings as well as fortify the religious doctrines.

Despite some similarities to images of hell which can easily be found in sermons of various major religions of the world, the Indonesian Islamic rhetoric has created unique characteristics of local images which mostly involve images of the corpses and the cemetaries. The typical descriptions of afterlife images do not seem to have touched the Indonesian people as much as the recent widely disseminated afterlife images shown on Indonesian TV miniseries. The popular soap opera which is called "sinetron kuburan" (graveyard miniseries) features images of hell that are more detailed and more specific to Indonesia, are portrayed in the form of horrible or sickening punishments right after death that are observable by the living.

While the utilization of afterlife images such as these may have the benefits of the portrayal of hell described above, I believe that there are further implications of attitudes and motives contained in the strategic employment of these afterlife images as well as reasons behind their popularity that yearn further examination and explanation.

The purpose of this paper is, therefore, not only to discuss the popularity of the use of afterlife images of punishment and how it is portrayed in speeches and media in Indonesia, but also to reveal the significance and

\footnotetext{
4 Ibid.

${ }^{5}$ Lecretius, On the Nature of the Universe, translated by Ronald Latham (New York: Penguin, 1977).

${ }^{6}$ Cicero, Philippics, translated by D.R. Shackleton Bailey, (Chapel Hill: The University of North Carolina Press, 1986).

7 Peter Stanford, The Devil: A Biography.
} 
possible motives behind such portrayal. For this purpose, I will employ two interconnected theories of rhetoric proposed by Kenneth Burke ${ }^{8}$ : identification and logology, based on the arguments that identification is essential in human communication including religious rhetoric and that logology (words concerning human's words) is analogous to theology (words about gods). With these theories, I hope to further explain the motives and attitudes contained in images of afterlife punishment described in religious speeches and media in Indonesia and their significance in the life of the Indonesian religious people.

\section{B. Burke's Identification and Logology}

In his book, A Rhetoric of Motives, Kenneth Burke uses the term "identification" in his attempt to depart from the traditional theory of communication which emphasizes "persuasion." For Burke, the complexities of human communication cannot solely be viewed as persuasion which suggests overt and deliberate effort to influence a specifically targeted audience. Burke explains that identification as a fundamental process in human communication arises out of division (disagreement, differences, diversity, misunder-standing, etc); because naturally humans are separate beings since birth and, therefore, strive for identification, through communication, in order to overcome division and separateness.

In addition to our biological separateness, we are also trapped in our man-made social, political, economic, ethnic and even religious divisiveness, in which we struggle for identification throughout our lives. Ironically, our effort of association or identification also creates dis-identification or division. For example, an effort to identify ourselves with a particular religion will consequently separate us from other groups and religions. This is the ambiguity we have to experience for being separate from yet, at the same time, united with others; or as asserted, humans are "both joined and separate, at once a distinct substance and consubstantial with another." 9

8 See K. Burke, A Rhetoric of Motives, (Berkeley: University of California Press, 1969) (Original work published 1950), and K. Burke, The Rhetoric of Religion: Studies in Logology, (Berkeley: University of California Press, 1970).

${ }^{9} \mathrm{~K}$. Burke, A Rhetoric of Motives, p. 21. 
Human communication which creates separateness is complicated by the spirit of hierarchy and order. This is true, because we live in a hierarchical society where we strive not only for identification but also to move up the ladder of the society by following and sometimes violating societal order. Human communication which constitutes our efforts to move up the hierarchical society is the basis for Burke theory called "logology."

Logology, "words about words," is one of Kenneth Burke's major works in theories of rhetoric to reveal the mystery of human motives and attitudes in their language use. He explained logology based on its analogy to theology, a verbal system which constitutes "words about God." Using Christian theology as a model, Burke asserts that language use creates and, at the same time, relies on hierarchies, which become the basis for humanstruggle to move up to a higher level of knowledge and of life. Upward movement is enabled by using language as "the negative." Language as the negative allows humans not only to create relationships among ideas and symbols that are not related (such as labeling things that they are not), but also to creatively negate what has been accepted as the standards and perceived as the truth. The process of negating and criticizing the conventional standards and the effort to create new values and principles within this socially constructed hierarchical framework provides humans with a cycle of order and disorder. In theology, this cycle is realized in the form of "order/law-guilt-purification." This cycle constitutes a sense of failure (sin/ guilt) or inability to follow the order which leads to humans' endeavor toward improvement and perfection (purification through redemption), thus, creating a new perfect order. At one point, however, this phase will be perceived as "not perfect enough" (creating guilt for not following the new perfect order/law); thus, people will restart the cycle toward the next ultimate perfection.

For Burke, the sequence of the cycle described above, which is based on Christian theology of atonement by sacrifice, can be applied to reveal human motives and attitudes in their language use and speeches. Burke's poem cited below summarizes his idea of the cycle:

"Here are the steps

In the iron Law of History 
That Welds Order and Sacrifice

Order leads to Guilt

(for who can keep commandments)

Guilt needs Redemption

(for who would not be cleansed)

Redemption needs Redeemer

(which is to say, a Victim)

Order

Through Guilt

To Victimage (hence: Cult of the kill)"10

Burke believes that this cycle constitutes "the representative anecdotes" common to most, if not all, religions. Since this theology of atonement by sacrifice is central not only to Christianity but also to the nature and mystery of human languages and human speeches, logology should be readily applicable to the analysis of religious rhetoric in Indonesia. This is especially true, because both Islamic doctrines and Christian theology center on the notion of cleansing to achieve purity; they are built on the idea of order by the use of "thou shalt not" and disobedience against these covenants entails sins and guilt which needs redemption, and redemption requires sacrifice.

\section{Identification: Who Goes to Hell}

The common use of antitheses in many religious speeches follows Burke's theory of identification as the basis of any human communication.

The very frequent employment of good versus evil, reward versus punishment, heaven versus hell makes religious rhetoric one of the most direct and open endeavors of identification in human communication. As a matter of fact, one can argue that no other institutions are more shamelessly direct, overt, and shamelessly consistent in their effort of identifying and dividing human beings as shown in the way they contrast between believers and non-believers. This identification not only affirms the separation between particular groups of religious followers from any other groups, but also points the identification of who should be rewarded (going to heaven) and who should be punished (going to hell).

\footnotetext{
${ }^{10} \mathrm{~K}$. Burke, The Rhetoric of Religion, p.p 4-5.
} 
The speeches or plays that portray various forms of torments clearly point not only to the kind of punishment in hell, but more importantly also to the kind of people who should be punished and be perceived as the common enemies. One of the most common identification of those that should be punished includes non-believers (infidels and atheists), apostates, heretics, and blasphemers. However, there are also more specific identifications of the unrepentant sinners that should be severely punished: corrupt government officials, prostitutes, gamblers, thugs, and drug addicts. These people are described as the ones who will be thrown, forced to enter, or fall off into a pit or lake of eternal fires. In some sermons, and in most of the religious TV miniseries, the torment of hell is detailed for specific individuals with specific acts and behaviors.

In some cases, the punishment occurs during the life time, but in many others, the punishment takes place during the process of dying or right after death such that these punishments are clearly observable to the livings. This kind of punishment during the dying process or right after death can also be found in anecdotes and narratives based on traditional beliefs and not necessarily contained in the popular religious doctrines. For example, children rebelling against parents will die miserably or the corpse of a farmer who annexed his neighbors' land will be difficult to bury, and wives disrespecting their husbands will endure a difficult dying process.

Although this kind of punishment portrayed on television miniseries usually take place in Muslim communities involving Islamic rituals, some portrayals of punishment are clearly loaded with cultural values and local mysticism.

The hell portrayed in the Indonesian TV miniseries detailed the punishments for specific acts of specific sinners that are taken directly from the commonly perceived societal sinners called "penyakit masyarakat" (abbreviated as PEKAT, meaning "the ills of society"). The police frequently conducts raids against and arrests of thugs, gamblers, drug edicts/dealers, prostitutes, and alcohol merchants. These ills of societies (PEKAT) are closely related to the Javanese concept of ma-lima (the five Ms referring to five common societal ills beginning with the letter $\mathrm{M}$ ); these include: maling (theft), madat (illegal drug), madon (adultery), main (gambling), and minum (drinking). These sinners' punishment varies depending on the type of sin 
committed, but most either die miserably or their corpses show signs of torture after death and during or right after burials.

Although there are varieties of damned sinners, in general the people identified as the sinners and source of societal ills that deserve these punishments can be classified as follows.

\section{Common Sinners}

Thieves, corrupt government officials, gamblers, drug addicts, sadistic murderers have long been accepted as the unrepentant sinners and common enemies that deserve the most severe punishment. In the miniseries, the display of punishment is usually in the form of gory tortures of the body or corpse during the dying process or the burials, ranging from the continuous bleeding from the corpses visible to those who attend the funerals to the swollen and smelly corpses. There seems to be no sympathy for these common sinners from any groups or segment of any Indonesian society, such that even if the drama of torments against them is shown repeatedly in media and sermons, people still enjoy receiving this confirmation that those who may go unpunished in this world will suffer the fire of hell during afterlife.

\section{a. Women}

Among many groups described in the drama of torment, women seem to be ones most frequently portrayed as ill-fated sinners that deserve severe punishment. There are many of the dramas of torment for women who become the source of sexually related sins, such as prostitutes. The facts that the Indonesian police in many different cities regularly conduct various raids arresting alleged prostitutes and there is no protest against them indicate that the Indonesian people generally accept prostitutes as the common enemies. What is intriguing is that the severe punishment is portrayed not only to fall upon promiscuous women such as erotic dancers, but also on anywomen who go out of their ways to beautify themselves to attract the opposite sex. One example is a miniseries play portraying a sinden (traditional singer accompanying Javanese traditional orchestra called gamelan) who usually sings at night, is associated with nightlife, is usually surrounded by male musical players or dancers, and, thus, is considered utterly promiscuous. 
Sindens are assumed to focus on maintaining and improving their beauty to sexually attract males. The punishment was shown in the face of the dead body where the eye lashes extended all over her rotten face. A similar play describes the punishment of a beautiful woman who wears susuk (a golden pin believed to have a magical charm that beautifies one' $s$ appearance). Another play portrays a beautiful woman who died with her chest rotten and bloody. The sin of the woman was not very clear except for the fact that beautiful women tend to beautify themselves to attract the opposite sex which creates sins. Portrayal of women such as these sinners creates questions in terms of whether or not they are really unrepentant sinners that deserve severe afterlife torments, because people from different groups may consider their actions, although not acceptable, not to violate local norms and values.

\section{b. Blasphemers}

Another group identified as enemies whose sins and punishment maybe questionable is blasphemers. The idea that it is sinful not to embrace certain faith is biased and sectarian, because certain groups of people with different faiths can be considered sinners by other groups of people embracing different beliefs. Examples of such sinners portrayed as enemies deserving punishment include a person who mocks and insults the Islamic call to prayers (azan) being punished by having his corpse transformed into a mad dog. In another episode, dukun (traditional healers or shamans) are portrayed as enemies and those frequenting dukun die with protruded eyes, wide open mouth, and tongue sticking out. Another example of blasphemers whose punishment is portrayed in the TV drama of torment is a man who insults and mocks the Quran Holybook. ${ }^{11}$ However, one of the most common sinners damned in various drama of torments found not only in TV miniseries, but also in sermons and other media are the kafirs (infidel, nonbelievers). The TV miniseries, for example, describe the agonizing screams of the kafirs enduring unbearable torture inside their grave yard.

11 The scene is described in detail, citing verses from the Holy Quran. See for example, http://www.youtube.com/watch?v=t1w5kXkIoOI 
The motives behind these portrayals of sinners deserving punishments may not be to safeguard civic morality. The identification of the damned indicates that not all of the various Indonesian groups totally agree with selected victims. Identifying the blasphemers as the scapegoat and the source of the ills of the society may go well with the expectation of some devout moslem believers but not with those of the other religious groups. In the same manner, victimizing the sindens may not fit with the values and norms embraced by Javanese traditional artists. By the same token, condemning the dukuns and their clients may not sit well with the traditional belief of many Indonesian people who still have faith in shamans and traditional healers. Even more compelling is the drama of the damnation of kafirs, where kafir is a subjective terms since two different religious sects may consider each other kafirs. Therefore, the identification of these sinners as scapegoats must have been intended to defend a certain religious belief and teaching as well as to strengthen a particular group by confronting its followers with the portrayed sinners as common enemies, including anyone or any group that could pose a threat to the preservation of the particular religious belief and faith.

\section{Logology: The Imagination of Hell as Ritual of Cleansing}

Burke's identification theory applied in analyzing the afterlife images from the Indonesian TV miniseries above not only describes the kinds of people considered sinners that deserve punishment, but also reveals the possible motives for the portrayal of selected sinners. That is, the portrayal of afterlife punishment constitutes an attempt to persuade the audience and the society to view certain groups of people as the condemned common enemies. Furthermore, the portrayal of the tormented common enemies fulfills the need for scapegoats that are responsible for the ills, wrongs, and sufferings of the society. This argument follows Burke's theory of logology describing how a guilty society needs a victim in order to redeem its guilt as well as to obtain purification.

The imagination of hell described above follows a cycle of purification as suggested in logological analysis proposed by Burke where the order leads to guilt, the guilt yearns redemption, the redemption requires a sacrifice, and the sacrifice needs a victim or scapegoats. Below is the description on how 
"order-guilt-purification through redemption" cycle is applied to the Indonesian portrayal and imagination of hell.

\section{a. Order}

In a religious society like Indonesia, the rhetoric of order is complicated not only by the changes in various rules throughout its democratization process, but also by the power and influence of religious values on the changing rules and laws. These changes are complicated by neglected inconsistencies between the state ideologies or constitutions and new bills passed by the lawmakers as well as new, local, and religiously inspired laws such as the implementation of some versions of sharia laws in some districts and municipalities. One of the most controversial bills, for example, is a pornographic bill including local rules that prohibit women from traveling alone at night. ${ }^{12}$

The idea of order in Indonesia is even more complicated by the power and influence of some religious leaders and institutions. For example, Indonesia has a quasi-government agent of MUI (Majelis Ulama Indonesia) ${ }^{13}$ or the Indonesian Council of Ulema, whose main task is to come up with fatwa or edicts that provide guidance in dealing with new, controversial, emerging issues in Muslims' communities. Although the edicts issued by MUI are nonbinding, MUI has recently gained more political influence such that even President Soesilo Bambang Yudoyono supports MUI's edicts. ${ }^{14}$

That is why, MUI's edicts are often perceived as a religious covenent containing many detailed do's and don'ts or "thou shalt not" including, among

\footnotetext{
12 There have been many discussion protesting the bills of Tanggerang district which lead to the arrest of women considered acting promiscuously, see for example: http://groups.yahoo.com/ group/ppiindia/message/51671?l=1

13 The Indonesian Council of Ulemas was founded on July 26, 1975 during the Soeharto military regime as a consultative council that bridges the gap between Islamic leaders and the state. With its members consisting of Muslim leaders, clerics, and intellectuals who used to be conforming to the dictator's policy, has increasingly been independent from government and has even been showing more power by issuing various controversial edicts.

14 See, for example, the report of Lembaga Pembinaan dan Pengembangan TK/TP al-Qur'an (LPPTKA) on Thursday, October 4, 2007, where Soesilo Bambang Yudoyono (the Indonesian President) expressed his supports of MUI edicts during the opening of MUI national meeting on November 5, 2007.
} 
others: a) Thou shalt not save money in a conventional bank (bank interest is haram); b) thou shalt not participate in Christmas celebrations; and c) thou shalt not participate in inter-religious vigil led by non-Muslims.

One of the most common arguments against these new rules is that these biblically based rules can eliminate local norms, traditions, and culture. That is why, although these rules have been viewed as an attempt to create order by preventing people from committing sin, they can eliminate local culture and tradition as well as constitute an effort to indentify an increasing number of new sinners. This is true, because the rules are not only to be followed, but also bound to be broken and violated, creating an additional pressure for feeling sinful and guilty.

\section{b. Sin and Guilt}

Sin and guilt is a big part of Indonesian discourse, not only because Indonesia is a religious country whereby people tend to express religious views in their communication, but also because the they tend to attribute their suffering to their sins. The religious discourses are the ones constantly preaching the continuous, rampant violation of the order or rules, but this creation of sin and guilt as part of the wrong and ills is also commonly depicted in various political and social discourses in Indonesia, especially when it comes to issues related to poverty, backwardness, insecurity, immorality and various uncertainties.

When it comes to societal ills, there are more than enough reasons for Indonesian people to complain about. The majority of the Indonesian people have been suffering for generations. According to World Bank, more than 52 percent of 245 million Indonesians live on less than US $\$ 2$ per day and around 35 million poor people live on less than US $\$ 0.65$ per day. ${ }^{15}$

Unemployment is very high; crime and various injustices occur in daily life of the majority of ordinary people. In addition, Indonesia has experienced some of the worse natural disasters in the history of mankind, including tsunami that killed more than 150, 000 people in Aceh, Earthquake that killed

15 Based on a report by World Bank, as shown ,for example, in: http://news.bbc.co.uk /1/hi/business/the_economy/124839.stm or http://www.wfp.org/ countries/indonesia 
over 5000 people near Yogyakarta, and hundreds of thousands of people displaced by mud flood in East Java.

Not surprisingly, religious speeches focus on these ills and wrongs of the Indonesian society in order to encourage the hopeless Indonesian people to turn to religion which will provide them hope. Despite the hopes that religions can offer, thepeople find many reasons to be disappointed and angry at whatever causes their suffering because of the overwelming narratives of sins and suffrings in the Indonesian media and society.

\section{c. Redemption}

Based on Burke's logological theory, a strong perception of Indonesian society's ills yearns for causes and creates the desire for punishing those who craft this suffering. Although some political speeches help logically identify the source of the ills, religious speeches seem to have influenced the majority of the Indonesian religious people' s perception of the source of the ills.

The identification of these sources of societal wrongs constitutes a sacrifice of the scapegoats. In a less-democratic Indonesia, the scapegoats would be created by those in power; but in a more democratic Indonesia, although the scapegoats are still identified by the powerful individuals or groups, the scapegoats vary depending on the motives and ideologies of the powerful and influencial. As described above, the publicly approved scapegoats are usually criminals or individuals who actively participated in KKN, pekat (penyakit masyarakat) or ma lima, as well as blasphemers.

The depiction of the torment such as those described in TV miniseries titled azab kubur, will create the sense of eliminating and sacrificing the scapegoats as the source of the ills of society.

\section{d. Purification}

The rhetoric of punishing, sacrificing, and eliminating the source of guilt creates a sense of cleansing and purification. Purification is central in many religious doctrines as reflected in various rituals and religious practices. According to Burke the mere identification which separate the evil from the 
good people gives a vision of eliminating the sinners from the virtuous. Similarly, scapegoating which represents a rhetoric of sacrificing the sinners provide images of cleansing which is especially needed in a suffering society which long for scapegoats. In turn, the idea of punishing the damned scapegoats symbolizes purification, which is essential for an idea a renewal.

This vision of renewal, which follows Burke's cycle of order-guiltpurification, has been reiterated, dramatized, and participated or viewed by audience and religious followers forming a ritual of purification. The torment of hell that has continuously been broadcasted through TV miniseries as well as sermons in places of worship constitutes a significant ritualistic and symbolic function in the life of the Indonesian society. The images of torment provides satisfying drama whereby the villains are being tormented as well as gives a vision wherebythe societal ills are eliminated.

\section{Conclusion}

In a religious society such as Indonesia, narratives of the torment of hell is commonly preached in places of worship or broadcasted in TV miniseries and other media. Although it has often been argued that the exploitation of images of hell can safeguard civic virtue and maintain religious doctrine, these images can also be exploited to achieve certain goals.

Using Burke's identification theory, this study explains that portrayal of torments of hell identifies certain groups of individuals as the damned sinners deserving specific punishments according to their sin. In addition, it fulfills the need for scapegoats for all the ills and suffering that the Indonesian people have to endure.

Following Burke's theory of logology, this study reveals that the depiction of torments of hell constitutes a ritual of purification. Based on the cycle of order, guilt, redemption through sacrifice to achieve purity, the images of punishment in hell are reflections of the challenges and complexity of rules and laws that are bound to be violated. This violation creates guilt and sin as realized in the form of all the troubles and hardship that the majority of Indonesians have to endure-a situation that begs scapegoats. The victims who are the scapegoats become the damned sinners, whose punishment constitutes a sacrifice, creating contentment and a sense of being cleansed. 
These images of hell which depict the above cycle of purification and are repeated in various media and places of worship, constitute a ritual of cleansing in religious Indonesian society. It should not be surprising that this kind of ritual received positive reception, as shown in the consistently high rating received by TV miniseries that shows religious and mystical plays with torments of hell.[w] 


\section{BIBLIOGRAPHY}

Burke, K, A Rhetoric of Motives, Berkeley: University of California Press, 1969, (Original work published 1950).

Burke, K., (The Rhetoric of Religion: Studies in Logology, Berkeley: University of California Press, 1970.

Cicero, Philippics, translated by D.R. Shackleton Bailey, Chapel Hill: The University of North Carolina Press, 1986.

Lecretius, On The Nature of The Universe, translated by Ronald Latham, New York: Penguin, 1977.

Seymour, Charles, A Theodicy of Hell. Studies in Philosophy and Religion, Dordrecht, The Netherlands: Kluwer Academic Publishers, 2000.

Stanford, Peter The Devil: A Biography, London: William Heinemann Ltd., 1996.

Turner, Alice K, The History of Hell. New York: Harcourt Brace \& Company, 1993.

Walls, Jerry L., Hell: The Logic of Damnation, Notre Dame: University of Notre Dame Press, 1992. 